\title{
HUBUNGAN PENGGUNAAN APD MASKER TERHADAP RISIKO GANGGUAN PERNAFASAN ISPA PADA PEKERJA INDUSTRI PENGOLAHAN KAYU DI WADASLINTANG
}

\author{
Sarwono $^{1 *}$, Pristi Yudyastanti ${ }^{2}$, Marsito ${ }^{3}$ \\ 1,2,3 Universitas Muhammadiyah Gombong \\ Jalan Yos Sudarso 461 Gombong, Kebumen, Indonesia \\ *E-mail: ronifah @gmail.com
}

\begin{abstract}
Keywords:

Industri Kayu, APD

Masker, ISPA

Latar Belakang : Pada industri pengolahan kayu di Indonesia 10-13\% debu kayu hasil industri berpotensi menyebabkan gangguan pernafasan seperti ISPA. Setiap tahunnya terjadi 160 kasus gangguan pernapasan pada pekerja industri pengolahan kayu. Masker menjadi salah satu APD yang berfungsi mengurangi debu kayu yang masuk kedalam paru-paru. Berdasarkan hasil observasi sebagian besar pekerja industri pengolahan kayu UD. Trans Jaya di Kecamatan Wadaslintang tidak menggunakan APD masker saat bekerja sebanyak $80 \%$ dari 38 pekerja. Tujuan : Untuk mengetahui hubungan penggunan APD masker terhadap risiko gangguan pernafasan ISPA pada pekerja industri pengolahan kayu di Wadaslintang. Metode : Penelitian ini menggunakan metode deskriptif analitik dengan studi pendekatan cross sectional, dengan sampel berjumlah 38 orang yang diambil mengggunakan teknik total sampling. Hasil penelitian menunjukan terdapat hubungan yang signifikan antara frekuensi penggunaan APD masker terhadap risiko gangguan pernafasan ISPA dengan uji Chi-Square p 0,025. Kesimpulan : Kesimpulan yang diperoleh yaitu terdapat hubungan yang signifikan antara pengetahuan dan frekuensi penggunaan APD masker terhadap risiko gangguan pernafasan ISPA pada pekerja industri pengolahan kayu di Wadaslintang. Rekomendasi : Pemilik industri pengolahan kayu diharapkan dapat menyediakan APD masker, serta adanya kesadaran mengenai pentingnya menggunakan APD masker saat bekerja bagi pekerja.
\end{abstract}

\section{PENDAHULUAN}

Industri pengolahan kayu di Indonesia menjadi sektor industri yang terus berkembang, sehingga membuat peningatan tenaga kerja didalamnya. Proses pengerjaan di industri pengolahan kayu antara lain proses penggergajian, proses pengadaan kayu, proses penyiapan bahan baku, perakitan, dan proses akhir seperti penghalusan dan pengepakan (Depkes RI, 2020). Dalam kemajuan bidang industri tersebut, memberikan dampak positif maupun negatif bagi pekerja dan lingkungan. Dampak negatif dari kegiatan tersebut berpotensi sebagai penyebab pencemaran yang akan membahayakan kesehatan pekerja serta lingkungan sekitar, terlebih lagi jika para pekerja mengabaikan penggunaan alat perlindung diri (Khumaida, 2010). Pada industri meubel sekitar 10 sampai $13 \%$ debu kayu hasil penggergajian dan pengahalusan yang bertebangan diudara sangat berpotensi menyebabkan polusi udara bagi pekerja (Yunus, 2010). Kesadaran para pekerja mengenai

pentingnya kesehatan dan keselamatan kerja di Indonesia termasuk dalam kategori rendah, dari hasil survei yang dilakukan oleh International Organitation (ILO) tahun 2015 bahwa Indonesia masuk pada peringkat kedua terendah dari 100 negara dalam program kesehatan dan keselamatan kerja. ILO melaporkan penyebab kematian 
dikarenakan oleh pekerjaan yaitu penyakit kanker sebanyak 34\%, kecelakaan $25 \%$, Penyakit pada sistem pernafasan $21 \%$, penyakit kardiovaskuler $15 \%$, serta penyebab lainnya sebanyak 5\% (Fahmi, 2012).

Debu kayu bersifat partikular yang berbahaya, apabila masuk kedalam saluran pernafasan akan meyebabkan gangguan pernafasan pada pekerja. Para pekerja di industri pengolahan kayu memiliki risiko besar terjadinya penimbunan debu kayu pada saluran pernafasannya. Debu kayu yang terhirup oleh pekerja akan masuk pada sitem pernafasan dan tertahan di jaringan paru-paru seiring dengan rutinnya paparan terhadap debu kayu (Fujianti et all, 2015). Menurut (BPS, 2010) jumlah karyawan mebel di Indonesia adalah 219,641 pekerja, setiap tahunnya terjadi 160 kasus gangguan pernapasan pada pekerja mebel.

Sehingga penggunaan alat pelindung diri (APD) pada pekerja menjadi salah satu bagian wajib digunakan dalam menjaga kesehatan dan keselamatan kerja. Semakin rendah frekuensi penggunaan APD makan semakin besar risiko kesehatan dan keselamatan kerja yang dapat terjadi. Akan tetapi masih banyak pekerja yang masih mengabaikan fungsi dari alat pelindung diri, dengan banyak faktor yang mempengaruhinya (Edwina Rudyarti, 2017).

Penyakit atau kecelakaan kerja dapat dimimalisir dengan penggunaan APD misalnya masker untuk mecegah debu terhirup kedalam saluran pernafasan yang dapat menimbulkan penyakit seperti ISPA, asma, pneumokonisis, dan lain sebagainya. Penggunaan APD masker berdasarkan aturan Menteri Tenaga Kerja dan Transmigrasi No.8/Men/ VII/2010. Hasil observasi data studi pendahuluan sebagian besar pekerja industri pengolahan kayu UD. Trans Jaya di Kecamatan Wadaslintang tidak menggunakan APD masker saat bekerja sebanyak $80 \%$ dari 38 pekerja.
Menurut data dari Riskesdas prevalensi ISPA Provinsi Jawa Tengah pada tahun 2016-2018 secara berturut-turut yaitu $54,3 \%, \quad 50,5 \%, 62,5 \%$ dan terjadi peningkatan kasus dari tahun 2017 sampai 2018 (Kemenkes RI, 2019). Kasus ISPA di Kabupaten Wonosobo menurut data dari Riskesdas RI tahun 2018 sebanyak 4,72\% (Kemenkes RI, 2018).

Berdasarkan latar belakang dari masalah yang telah dibahas, mendorong peneliti untuk membuktikan apakah ada pengaruh penggunan APD masker terhadap risiko gangguan pernafasan ISPA pada pekerja industri pengolahan kayu di Wadaslintang.

\section{METODE PENELITIAN}

Pada penelitian ini menggunakan metode deskriptif analitik dengan pendekatan cross sectional dengan menggunakan uji Chi-Square. Penelitian ini dilakukan pada pekerja industri pengolahan kayu di Wadaslintang yaitu UD. Trans Jaya dengan jumlah pekerja 38 orang, dengan waktu penelitian dari tanggal 1 Juni - 30 Juni 2021.

\section{HASIL PENELITIAN}

Tabel 1 Distribusi Frekuensi Karakteristik Responden Berdasarkan Jenis Kelamin, Usia, Pendidikan, Lama Kerja di Industri Pengolahan Kayu UD. Trans Jaya

\begin{tabular}{lcc}
\hline $\begin{array}{l}\text { Karakteristik } \\
\text { Responden }\end{array}$ & Frekuensi & $\begin{array}{c}\text { Presentase } \\
(\%)\end{array}$ \\
\hline Jenis Kelamin & & \\
Laki-laki & 38 & 100 \\
Perempuan & 0 & 0 \\
Jumah & 38 & 100 \\
Usia & & \\
17-25 Tahun & 2 & 5,3 \\
26-35 Tahun & 14 & 36,8 \\
36-45 Tahun & 12 & 31,6 \\
46-55 Tahun & 10 & 26,3 \\
Jumlah & 38 & 100 \\
Pendidikan & & \\
SD/Sederajat & 13 & 34,2 \\
SMP/Sederajat & 19 & 50,0 \\
SMA/Sederajat & 6 & 15,8 \\
Jumlah & 38 & 100 \\
Lama Kerja & & \\
< 5 Tahun & 15 & 39,5 \\
> Tahun & 23 & 60,5 \\
Jumlah & 38 & 100 \\
\hline
\end{tabular}


Berdasarkan tabel 1 menunjukan bahwa jenis kelamin responden di UD. Trans Jaya adalah berjenis kelamin laki-laki sebanyak 38 orang $(100 \%)$. Sebagian besar pekerja berusia 26-35 tahun sebanyak 14 orang (36,8\%). Dengan pendidikan responden sebagian besar SMP/Sederajat sebanyak 19 orang $(50,0 \%)$. Berdasarkan karakteristik lama kerja responden sebagian besar responden bekerja lebih dari 5 tahun yaitu sebanyak 23 pekerja $(60,5 \%)$.

Tabel 2 Distribusi frekuensi pengetahuan penggunaan APD masker pada pekerja industri pengolahan kayu

\begin{tabular}{cccc}
\hline No. & $\begin{array}{c}\text { Pengetahuan Penggunaan } \\
\text { APD Masker }\end{array}$ & Jumlah & $\%$ \\
\hline 1. & Baik & 22 & 57,9 \\
2. & Kurang Baik & 16 & 42,1 \\
Jumlah & 38 & 100 \\
\hline \multicolumn{2}{c}{ Berdasarkan tabel } & 2 & diketahui
\end{tabular}

bahwa pengetahuan penggunaan APD masker pekerja industri pengolahan kayu UD. Trans Jaya sebagian besar adalah kategori baik sebanyak 22 orang $(57,9 \%)$.

Tabel 3 Distribusi frekuensi penggunaan APD masker pada pekerja industri pengolahan kayu

\begin{tabular}{clcc}
\hline No. & $\begin{array}{c}\text { Frekuensi Penggunaan } \\
\text { APD Masker }\end{array}$ & Jumlah & $\%$ \\
\hline 1. $\quad \begin{array}{l}\text { Menggunakan Dengan } \\
\text { Baik }\end{array}$ & 10 & 26,3 \\
$\quad \begin{array}{l}\text { Tidak Menggunakan } \\
\text { Dengan Baik }\end{array}$ & 28 & 73,7 \\
Jumlah & 38 & 100 \\
\hline
\end{tabular}

Berdasarkan tabel 3 diketahui bahwa frekuensi penggunaan APD masker pekerja industri pengolahan kayu UD. Trans Jaya di Wadaslintang sebagian besar adalah tidak mengunakan dengan baik sebanyak 28 orang $(73,7 \%)$

Tabel 4 Distribusi frekuensi gangguan pernafasan ISPA pada pekerja industri pengolahan kayu

\begin{tabular}{clcc}
\hline No. & $\begin{array}{c}\text { Gangguan Pernafasan } \\
\text { ISPA }\end{array}$ & Jumlah & $\%$ \\
\hline 1. Ada & 22 & 57,9 \\
2. Tidak Ada & 16 & 42,1 \\
Jumlah & 38 & 100 \\
\hline
\end{tabular}

Berdasarkan tabel 4 menunjukan bahwa risiko gangguan pernafasan ISPA yang teradi pada para pekerja industri pengolahan kayu UD. Trans Jaya di Wadaslintang sebagian besar mengalami risiko gangguan pernafasan ISPA yaitu sebanyak 22 orang $(57,9 \%)$

Tabel 5 Hubungan Penggunaan APD Masker Terhadap Risiko Gangguan Pernafasan ISPA Pada Pekerja Industri Pengolahan Kayu di Wadaslintang

\begin{tabular}{|c|c|c|c|c|c|c|}
\hline \multirow{3}{*}{$\begin{array}{l}\text { Frekuensi } \\
\text { Penggunaan }\end{array}$} & \multicolumn{4}{|c|}{$\begin{array}{c}\text { Gangguan Pernafasan } \\
\text { ISPA } \\
\end{array}$} & \multirow{3}{*}{$\%$} & \multirow{3}{*}{$\begin{array}{c}\mathrm{P} \\
\mathrm{va} \\
\text { lu } \\
\mathrm{e}\end{array}$} \\
\hline & Ada & Tidak & & \multirow[t]{2}{*}{$\mathrm{F}$} & & \\
\hline & F \% & $\mathrm{F}$ & $\%$ & & & \\
\hline Menggunakan & & & & & & \\
\hline Dengan Baik & 990 & 1 & 10 & 10 & 100 & 0,02 \\
\hline $\begin{array}{c}\text { Tidak } \\
\text { Menggunakan } \\
\text { Dengan Baik }\end{array}$ & 1346,4 & 15 & $\begin{array}{c}53 \\
6\end{array}$ & 28 & 100 & 5 \\
\hline
\end{tabular}

Berdasarkan tabel 5 menunjukan bahwa frekuensi penggunaan APD masker para pekerja industri pengolahan kayu UD. Trans Jaya di Wadasintang sebagian besar tidak menggunakan dengan baik yaitu sebanyak 28 orang dengan responden yang mengalami risiko ISPA sebanyak orang 13 $(46,4 \%)$ dan yang tidak mengalami risiko ISPA sebanyak 15 orang $(53,6 \%)$. Berdasarkan pengujian menggunakan uji statistik Chi-Square, didapatkan hasi nilai $\mathrm{p}=0,025$.

\section{PEMBAHASAN}

Industri pengolahan kayu merupakan tempat pengolahan kayu bulat atau gelondongan diolah menjadi produk kayu gergajian dan kayu lapis dengan berbagai bentuk dan ukuran. Setiap proses pengolahan kayu gergajian dan kayu lapis dihasilkan limbah kayu dengan berbagai ukuran, jenis dan jumlahnya. Macammacam limbah yang dihasilkan dari proses produksi di industri pengolahan kayu yaitu seperti serbuk kayu, debu kayu, sebetan dan potongan-potongan kayu kecil. Pada industri pengolahan kayu terpadu, limbah serbuk gergajian kayu dan potongan- 
potongan kayu akan dolah menjadi bahan pembuatan papan partikel (Djoko, 2010).

Debu kayu yang dihasilkan dari proses penggergajian kayu memiliki sifat partikular yang berbahaya untuk kesehatan sistem pernafasan manusia. Debu kayu yang terhirup oleh pekerja akan masuk dan mengendap di jaringan paru-paru dan beresiko menyebabkan penyakit pernafasan seperti ISPA (Kementrian Kesehatan, 2010).

Gangguan pernapasan ISPA merupakan penyakit infeksi yang menyerang salah satu bagian atau lebih dari saluran pernafasan, mulai dari hidung (saluran atas) hingga alveoli (saluran bawah) termasuk saluran adneksanya seperti sinus, rongga telinga tengah dan pleura. Penyakit ISPA dapat menular, seta dapat menimbulkan berbagai spektrum penyakit yang berkisar dari penyakit tanpa gejala atau infeksi ringan sampai penyakit parah dan mematikan (WHO, 2011).

Penyakit akibat kerja seperti ISPA dapat dicegah dengan mengguanakan alat pelindung diri misalnya masker untuk mencegah masuknya debu kedalam saluran pernafasan, sehingga penyakit akibat kerja dapat terkurangi jumlahnya. Penggunaan APD masker berdasarkan aturan Menteri Tenaga Kerja dan Transmigrasi No.8/Men/ VII/2010 tentang Alat Pelindung Diri bahwa pekerja yang memasuki tempat kerja wajib menggunakan APD sesuai dengan potensi bahaya dan risiko. (Pujiani, 2017). Penggunaan masker yang tidak lakukan secara rutin dapat mengakibatkan ISPA, dimana ISPA menjadi salah satu penyebab utama morbiditas penyakit menular di dunia. Penggunaan APD seperti masker merupakan upaya yang dapat dilakukan dalam mencegah dan mengendalikan ISPA (Rustika, 2016).

Berdasarkan penelitian yang telah dilakukan peneliti didapatkan hasil uji chi square dengan nilai Pvalue $=0,025$ dan ini lebih kecil dari $\alpha=0,05$ (Pvalue $=0,025<$ $\alpha$ 0,05), dengan nilai $\mathrm{CI}=(1,156-93,293)$ sehingga dapat diartikan bahwa terdapat hubungan yang signifikan antara faktor penggunaan APD masker terhadap risiko gangguan pernafasan ISPA pada pekerja industri pengolahan kayu di Wadaslintang. Dari hasi penelitian yang telah dilakukan terhadap 38 responden, sebagian besar responden tidak menggunakan dengan baik yaitu sebanyak 28 orang dengan responden yang mengalami risiko ISPA sebanyak orang $13(46,4 \%)$ dan yang tidak mengalami risiko ISPA sebanyak 15 orang $(53,6 \%)$. Pada kategori menggunakan APD masker dengan baik sebanyak 10 orang dengan responden mengalami risiko ISPA sebanyak 9 orang (90\%) dan yang tidak mengalami risiko ISPA sebanyak 1 orang $(10 \%)$.

Alat Pelindung Diri yang digunakan oleh pekerja yang diukur dalam penelitian ini adalah penggunaan masker. Responden yang aktivitasnya banyak terpapar oleh partikel debu memerlukan alat pelindung diri berupa masker untuk mereduksi jumlah partikel yang kemungkinan dapat terhirup. Responden yang taat menggunakan masker pada saat bekerja pada area yang berdebu akan meminimalkan jumlah paparan partikel debu yang dapat terhirup. Selain jumlah paparan, ukuran partikel yang kemungkinan lolos dari masker menjadi kecil (Budiono, 2010).

Menurut Halimah (2010) para pekerja hendaknya memiliki kesadaran mengenai pentingnya menggunakan alat pelindung diri saat bekerja sehingga risiko terjadinya kecelakaan atau risiko kerja dapat diminimalisir. Kesadaran terhadap bahaya yang mengancam dapat diwujudkan dengan mematuhi prosedur dan peraturan yang berlaku serta bekerja dengan bertanggung jawab. Hal ini dikarenakan bahwa pekerja yang tidak menggunakan APD saat bekerja memiliki risiko 5,38 kali mengalami ISPA dibandingkan pekerja yang menggunakan APD. APD pernafasan (khususnya masker) merupakan APD terpenting yang harus digunakan jika bekerja ditempat yang banyak menimbulkan debu sebanyak 90\% kasus keracunan merupakan akibat dari masuknya bahan-bahan kimia beracun atau 
korosi lewat saluran pernafasan (Naini, 2009).

Penelitian yang dilakukan oleh Chusman dan Rosenberg (2016) menyatakan bahwa penggunaan alat pelindung diri memiliki pengaruh terhadap kenyamanan pekerja karena menghambat gerak mereka, sehingga dalam bekerja menjadi lebih sulit dan adapun yang mengganggu komunikasi. Meskipun demikian hal tersebut bukan menjadi alasan untuk tidak menggunakan alat pelindung diri selama bekerja, melainkan melakukan penyesuaian supaya dapat bekerja dengan maksimal dan memenuhi standar keselamatan. Salah satu faktor para pekerja tidak menggunakan APD masker saat bekerja karna merasa ketidaknyamanan dalam bekerja. Peneliti berasumsi bahwa jika dalam bekerja mereka tidak menggunakanAPD masker akan berdampak pada kesehatan para pekerja sehingga menimbulkan masalah gangguan pernapasan.

Menurut Halimah (2010) para pekerja hendaknya memiliki kesadaran mengenai pentingnya menggunakan alat pelindung diri saat bekerja sehingga risiko terjadinya kecelakaan atau risiko kerja dapat diminimalisir. Kesadaran terhadap bahaya yang mengancam dapat diwujudkan dengan mematuhi prosedur dan peraturan yang berlaku serta bekerja dengan bertanggung jawab. Hal ini dikarenakan bahwa pekerja yang tidak menggunakan APD saat bekerja memiliki risiko 5,38 kali mengalami ISPA dibandingkan pekerja yang menggunakan APD. APD pernafasan (khususnya masker) merupakan APD terpenting yang harus digunakan jika bekerja ditempat yang banyak menimbulkan debu sebanyak 90\% kasus keracunan merupakan akibat dari masuknya bahan-bahan kimia beracun atau korosi lewat saluran pernafasan (Naini, 2009).

Sejalan dengan teori Khumaidah (2010) yang menyatakan apabila pekerja yang menggunakan masker akan melindungi diri dari kemungkinan terjadinya gangguan pernapasan akibat terpapar udara yang kadar debunya tinggi. Penggunaan Alat pelindung diri secara sederhana adalah seperangkat alat yang digunakan pekerja untuk melindungi sebagian atau seluruh tubuh pekerja dari adanya potensi bahaya atau kecelakan kerja. Pekerja yang aktivitas pekerjaannya banyak terpapar oleh partikel debu memerlukan APD untuk mereduksi jumlah partikel yang kemungkinan terhirup. Selain jumlah paparan, ukuran partikel yang kemungkinan lolos dari masker menjadi kecil. Budiono (2010).

\section{SIMPULAN}

1. Karakteristik pekerja industri pengolahan kayu UD. Trans Jaya di Wadaslintang semua berjenis kelamin laki-laki sebanyak 38 orang (100\%), dengan usia 17-25 tahun sebanyak 2 orang (5,3\%), 26-35 tahun sebanyak 14 orang $(36,8 \%)$, usia 36-45 Tahun sebanyak 12 orang (31,6\%), usia 46-55 Tahun sebanyak 10 pekerja $(26,3 \%)$. Pendidikan pekerja industri pengolahan kayu UD. Trans Jaya di Wadaslintang sebagian besar pendidikan terakhir SMP sebanyak 19 orang (50\%), SD 13 orang $(34,2 \%)$, dan SMA 6 orang $(15,8 \%)$. Lama kerja pekerja industri pengolahan kayu UD. Trans Jaya di Wadaslintang sebagian besar $>5$ tahun sebanyak 23 orang $(60,5 \%)$ dan $<5$ tahun sebanyak 15 orang $(39,5 \%)$. Sebagian besar pekerja industri pengolahan kayu di Wadaslintang memiliki tingkat pengetahuan kurang baik mengenai APD masker yaitu sebesar 22 orang $(57,9 \%)$.

2. Sebagian besar pekerja industri pengolahan kayu di Wadaslintang tidak menggunakan APD masker saat bekerja yaitu sebesar 28 orang $(73,7 \%)$.

3. Ada hubungan antara penggunaan APD masker terhadap risiko gangguan pernafasan ISPA pada pada pekerja industri pengolahan kayu di Wadaslintang dengan nilai $\mathrm{p}$ value 0,025 . 


\section{SARAN}

1. Bagi Tempat Penelitian

Diharapkan untuk memperhatikan kesehatan dan keselamatan para pekrja dengan menyediakan dan mewajibkan para pekerja untuk menggunakan APD masker saat bekerja untuk mengurangi faktor risiko kejadian ISPA

2. Bagi Institusi Universitas Muhammadiyah Gombong (UNIMUGO)

Peneliti menyarankan UNIMUGO dapat berperan serta dalam pemberian penkes mengenai pentingnya penggunaan APD masker saat bekera untuk mengatasi risiko ganguan pernafasan ISPA kepada para pekera industri pengolaan kayu.

3. Bagi Peneliti Selanjutnya

Perlu adanya penelitian lebih lanjut dengan memperluas variabel-variabel penelitian yang lain agar dapat diketahui faktor-faktor lain yang berhubungan dengan kejadian ISPA pada pekerja di industri pengolahan kayu, seperti banyaknya debu kayu yang terpapar pada pekerja dan pengaruh diadakannya program penyuluhan kesehatan terkait kejadian ISPA pada pekerja industri pengolahan kayu.

4. Bagi Responden

Para responden diharapkan untuk meningkatkan kesadaran dalam menggunakan Alat Pelindung Diri

(APD) seperti masker dan kelengkapannya selama bekerja yang bertujuan untuk melindungi diri dari risiko bahaya yang timbul serta memeriksakan kesehatan secara rutin ke layanan kesehatan setempat agar jika kondisi kesehatannya terganggu dapat segera ditangani sehingga tidak semakin parah.

\section{DAFTAR PUSTAKA}

[1] Budiono. (2010). Bunga Rampai Hiperkes da Kesehatan Kerja. Semarang: Badan Penerbitan UNDIP.
[2] Fahmi. (2012). Hubungan Masa kerja Dan Penggunaan APD Dengan Kapasitas Fungsi Paru Pada Pekerja Tekstil Bagian Ring Frame Spinning I Di PT "X" Kabupaten Pekalongan. Jurnal Kesehatan Masyarakat, 2(1).

[3] Halim. (2012). Hubungan Faktor Lingkungan Fisik Dengan Kejadian Infeksi Saluran Pernafasan Akut (ISPA) Pada Pekerja di Industri Mebel Dukuh Turkejo, Desa Bondo, Kecamatan Bandsri, Kabupaten Jepara. FKM UI.

[4] Kemenkes. (2013). Profil Kesehatan Indonesia. Departemen Kesehatan Republik Indonesia.

[5] Kemenkes. (2018). Pokok-Pokok Hasil Riskesdas) Provinsi Jawa Tengah 2018. Badan Penelitian Dan Pengembangan Kesehatan Kementrian Kesehatan RI.

[6] Kemenkes. (2019). Profil Kesehatan Indonesia 2018. Kemenkes RI.

[7] Khumaida. (2010). Analisis faktorFktor Yang Berhubungan Dengan Gangguan Fungsi Paru Pada Pekerja Mebel PT Kota Jambi Furnindo Desa Suwwal Kecamatan Mlonggo Kabupaten Jepara. Jurnal Kesehatan Masyarakat, Vol.4(3).

[8] Naini, Iis. 2009. Pajanan Debu Kapuk (PM10) dengan Kejadian ISPA Pada Pekerja Industri Kasur Kapuk di Kecamatan Bukit Kecil Kota Palembang Tahun 2009. Depok: Universitas Indonesia.

[9] Pujiani, Tr. R. (2017). Hubungan Penggunaan APD Masker, Kebiasaan Merokok dan Volume Kertas Bekas Dengan ISPA. Kesehatan.

[10] Rustika. (2016). Karakteristik, Pengetahuan dan Sikap Dengan Penggunaan Masker Dalam Upaya Pencegahan ISPA Pada Jemaah Haji Indonesia Di Arab Saudi. Jurnal Kesehatan Masyarakat.

[11] WHO. (2008). Pedoman Interim WHO Pencegahan dan Pengendalian Infeksi Saluran Pernafasan Akut (ISPA) Yang Cenderung Menjadi Epidemi dan 
Pandemi Di Fasilitas Pelayanan Kesehatan.

[12] Yunus.(2010). Pengaruh Keadaan Lingkungan kerja, Karakteristik
Pekerja, Dan Katar Debu Kayu Terhadap Kapasitas Vital Paru Pekrja Industri Meubel Di Kota Banda Aceh. Jurnal Kesehatan Masyarakat, 8(2). 